\title{
Correction to: HDAC6 deacetylates alpha tubulin in sperm and modulates sperm motility in Holtzman rat
}

\author{
Sweta Parab ${ }^{1} \cdot$ Omshree Shetty $^{1} \cdot$ Reshma Gaonkar $^{2} \cdot$ Nafisa Balasinor $^{2}$. \\ Vrinda Khole $^{1} \cdot$ Priyanka Parte $^{1}$
}

Published online: 18 November 2017

(C) Springer-Verlag GmbH Germany, part of Springer Nature 2017

Correction to: Cell Tissue Res (2015) 359:665-678

https://doi.org/10.1007/s00441-014-2039-x

The published online version contains mistake. The chimeric peptide should read as 'DPSVLYVSLHRYGGYMNEGELRV'. It was inadvertently written as 'DPSVLYVSLYVS LHRYGGYMNEGELR' a mistake which we missed during proof reading.

The online version of the original article can be found at https://oi.org/ 10.1007/s00441-014-2039-x

\section{Priyanka Parte}

partep@nirrh.res.in

1 Department of Gamete Immunobiology, National Institute for Research in Reproductive Health (ICMR), Mumbai 400012, India

2 Department of Neuroendocrinology and Confocal Microscopy Lab, National Institute for Research in Reproductive Health (ICMR), Mumbai 400012, India 